\title{
Polychlorinated Biphenyls (PCBs) in Urban Stream Sediments from Suzhou Industrial Park in China: Occurrence and Potential Risk
}

\author{
Zijiao Yuan ${ }^{1}$, Qing Wang ${ }^{1}$, Xiaoguo $\mathrm{Wu}^{1 *}$, Binbin $\mathrm{He}^{1}$, Houqi Liu ${ }^{2}$, \\ Shanshan Wang ${ }^{1}$ Zhiwen Jiang ${ }^{1}$ \\ ${ }^{1}$ Anhui Provincial Engineering Laboratory of Water and Soil Pollution Control and Remediation, \\ School of Ecology and Environment, Anhui Normal University, Wuhu, Anhui, 241002, PR China \\ ${ }^{2}$ Suzhou Institute for Advanced Study, University of Science and Technology of China, \\ Suzhou, Jiangsu, 215123, PR China
}

Received: 14 May 2021

Accepted: 10 September 2021

\begin{abstract}
The concentration, spatial distribution, homologue profiles, sources, toxicity and risk of PCBs in urban stream sediments from a national eco-industrial park named Suzhou Industrial Park (SIP) in China were investigated in this work. Concentrations of $\sum$ PCBs varied from 0.13 to $4.7 \mathrm{ng} \mathrm{g}^{-1}$, with an average value of $1.7 \pm 1.2 \mathrm{ng} \mathrm{g}^{-1}$. Spatial variations indicated that $\mathrm{PCB}$ concentrations had no correlation with land uses in the SIP. Tetra-PCBs and hexa-PCBs were the most abundant PCB homologues, which were different from those found in Chinese commercial PCBs and might be mainly derived from other sources. The potential toxicity and risk of PCBs here might be negligible based on the total equivalent concentration (TEQ) analysis and sediment quality guidelines (SQG).
\end{abstract}

Keywords: PCBs, urban stream sediments, eco-industrial park, potential risk

\section{Introduction}

PCBs were commercially produced since the 1930s and had been widely applied in capacitors and transformers, heat exchange fluids, paints, and some other industries [1-3] Owing to their persistence, toxicity, high ability to undergo long-range atmospheric transport, bioaccumulation, and adverse ecological or health effects, their production and usage were

*e-mail:wuxg1983@ahnu.edu.cn banned in the 1970s and have been designated as persistent organic pollutants in 2001 by the Stockholm Convention [4, 5]. Although most PCB-containing equipment have been carefully disposed of since the banning, PCB emissions have still been noted in the environment [6]. Besides, fuel combustion and some industrial thermal processes may also produce PCBs unintentionally [7]. Therefore, PCBs are still frequently detected in the environment today. In the aquatic environment, sediments are vital for the cycling of environmental contaminants and they are often considered as the ultimate reservoir for many anthropogenic pollutants such as PCBs [8]. 
SIP is a national eco-industrial park situated in Suzhou City, Jiangsu Province, China and was set up in 1994 on the cooperation between Chinese and Singaporean governments [9, 10]. The major industry of SIP are machinery manufacturing and the electronic industry, and there are other three characteristic emerging industries including biological medicine, artificial intelligence and nanotechnology. With the development of urban services, SIP has become complexes of residential communities and industrial manufacture step by step [11]. In addition, the industrialization of Suzhou has developed rapidly since 1994, many factories, such as steelworks, petrochemical and electroplate factories, were set up [12]. Under the collaboration model, SIP adopted knowledge on planning and management from Singapore, which has obtained a favorable environmental situation since its establishment [11, 13]. Nevertheless, the urban development also made the land cover of the SIP change, and most natural and arable soils have been replaced with impermeable artificial surfaces, such as roads. These impermeable surfaces may generate more runoff which will carry pollutant loads of human origin into urban streams and rivers [14]. The urban streams and rivers in the SIP are well developed and crisscrossed (Fig.1), but the occurrence, sources and potential risk of PCB residues here have not been figured out up to date. The objective of the present research is to fill in the information gap.

\section{Experimental}

Twenty-six urban stream surface sediment samples (0-10 cm depth) were collected from the SIP in 2018 (Fig. 1). The sampling process, sample preparation, extraction and purification, GC-MS analysis and the QA/QC were similar to our published research work $[5,10]$. Briefly, the sediment samples were spiked with PCB 30 and PCNB (surrogate standards) and were then extracted by a mixture of hexane and dichloromethane $(1: 4 \mathrm{v} / \mathrm{v})$ using an accelerated solvent extractor. The concentrated extracts were added into pre-cleaned multi-layer columns packed with anhydrous sodium sulfate, acid silica gel, deactivated silica gel and deactivated alumina, and then were eluted with a $30 \mathrm{~mL}$ mixture of dichloromethane and hexane $(1: 1 \mathrm{v} / \mathrm{v})$. The elutions were spiked with a known amount of TCMX (internal standard) and further concentrated to $100 \mu \mathrm{L}$. The PCB analysis was conducted using an Agilent 5977B mass-selective detector linked to a $7890 \mathrm{~N}$ gas chromatography and the separation was accomplished with an HP-5MS capillary column. A total of twenty-six PCB congeners (tri-PCBs to decaPCBs) were quantified, including PCB 28, 52, 44, 66, $81,77,101,123,118,114,105,126,153,138,128,167$, 156, 157, 169, 187, 180, 170, 189, 195, 206 and 209. The recoveries of PCBs from spiked anhydrous sodium sulfate $(\mathrm{n}=3)$ ranged from $80 \%$ to $120 \%$. The average surrogate recoveries were $79 \pm 14 \%$ for PCB 30 and

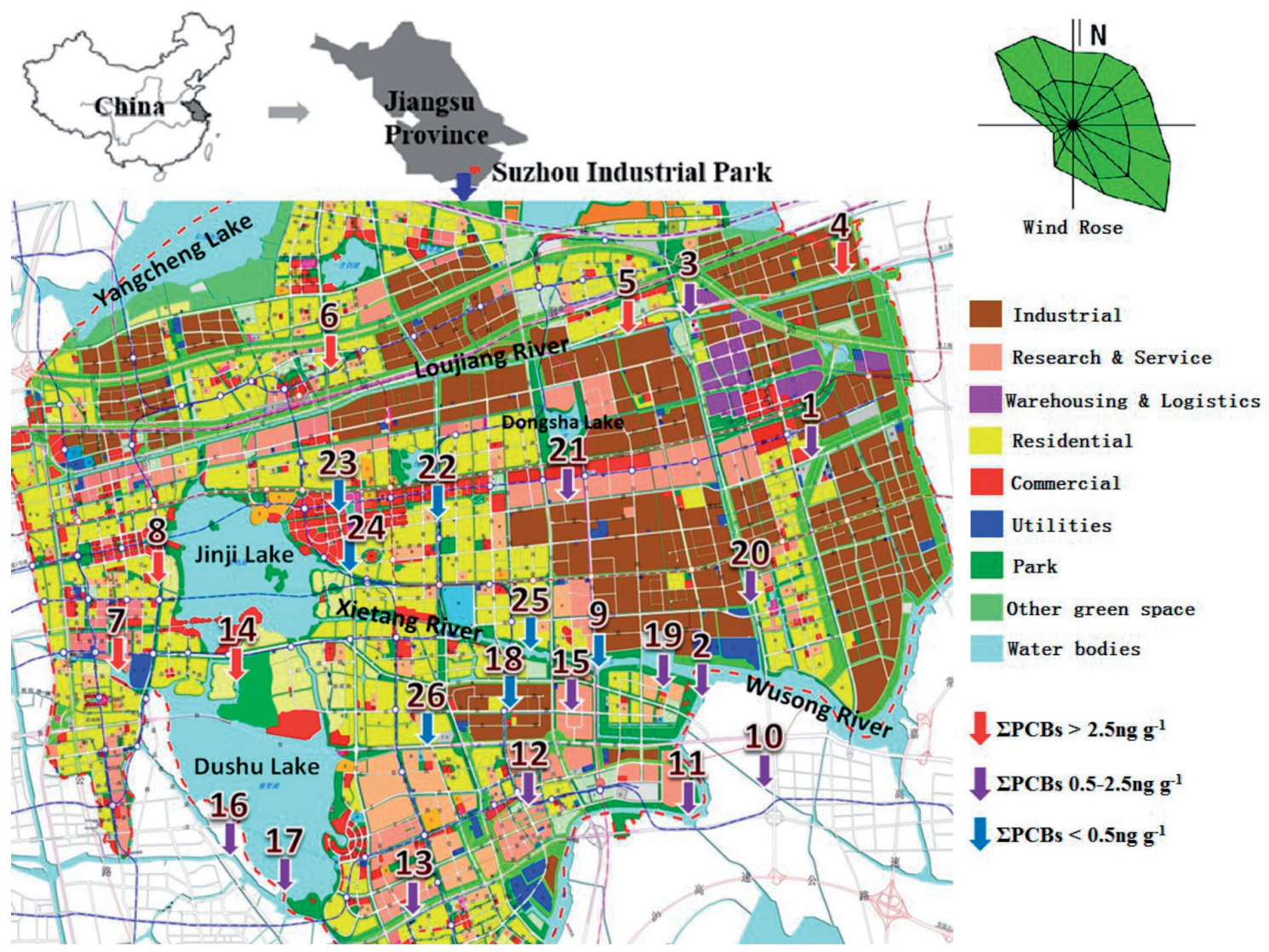

Fig. 1. Sampling locations of urban stream sediments in Suzhou Industrial Park, China $[10,15]$. 
$73 \pm 12 \%$ for PCNB spiked in all the sediment samples. All the PCB concentrations in the paper were calculated on a dry weight sample basis and were not corrected for surrogate recoveries.

\section{Results and Discussion}

Concentration and Spatial Distribution of PCBs

The individual concentration of PCBs in urban stream sediments of the SIP can be found in Table 1 . Except PCB 195 and PCB 209, the rest of the targeted $\mathrm{PCB}$ congeners were all detected here, indicating the ubiquity of PCB distribution in the SIP. Among them, PCB 52 was $100 \%$ detected. The other major PCB congeners with high detectable frequencies $(>75 \%)$ were PCB 66, 101, 81, 77 and 118, which belong to tetraand penta-PCBs. Concentrations of $\sum$ PCBs (Sum of all the detectable PCBs) varied from 0.13 to $4.7 \mathrm{ng} \mathrm{g}^{-1}$ (Mean: $1.7 \pm 1.2 \mathrm{ng} \mathrm{g}^{-1}$ ). These values were higher than that of the coastal East China Sea (Range: 0.024-0.34 ng g-1, Mean: 0.127 ng g ${ }^{-1}$ ) [6], Liaohe Estuary, China (Range: 0.11-0.27 ng g-1, Mean: 0.19 ng g-1) [16] and Makran region in Chabahr bay, Iran (Range: "not detected" $-0.49 \mathrm{ng} \mathrm{g}^{-1}$, Mean: $0.11 \mathrm{ng} \mathrm{g}^{-1}$ ) [17], but much lower than that of the highly urbanized regions such as Shanghai (Mean: $6.01 \mathrm{ng} \mathrm{g}^{-1}$ ) [18], the Yangtze River Estuary (Range: 2.2-40 $\mathrm{ng} \mathrm{g}^{-1}$, Mean: $14 \mathrm{ng} \mathrm{g}^{-1}$ ) [19], the Pearl River Delta (Mean: 122 ng $\mathrm{g}^{-1}$ ) [3], Potomac River in mid-Atlantic USA (Range: 1.8-158 ng g ${ }^{-1}$ ) [20], San Diego Bay in South California

Table 1. Concentrations of PCBs in urban stream sediments of Suzhou Industrial Park, China.

\begin{tabular}{|c|c|c|c|}
\hline PCB congeners & Range (ng g ${ }^{-1}$ ) & Mean \pm SD $\left(\right.$ ng g $\left.^{-1}\right)$ & $\mathrm{DF}^{\mathrm{b}}(\%)$ \\
\hline PCB28 & $\mathrm{ND}^{\mathrm{a}}-1.8$ & $0.25 \pm 0.47$ & 42 \\
\hline PCB52 & $0.039-2.0$ & $0.62 \pm 0.53$ & 100 \\
\hline PCB44 & ND-0.37 & $0.039 \pm 0.087$ & 50 \\
\hline PCB66 & ND-0.29 & $0.044 \pm 0.062$ & 88 \\
\hline PCB101 & ND-0.22 & $0.026 \pm 0.044$ & 88 \\
\hline PCB81 & ND-0.31 & $0.085 \pm 0.096$ & 85 \\
\hline PCB77 & ND-0.21 & $0.062 \pm 0.065$ & 77 \\
\hline PCB123 & ND-0.067 & $0.013 \pm 0.017$ & 54 \\
\hline PCB118 & ND-0.38 & $0.040 \pm 0.073$ & 85 \\
\hline PCB-114 & ND-0.085 & $0.017 \pm 0.021$ & 54 \\
\hline PCB153 & ND-0.061 & $0.014 \pm 0.018$ & 62 \\
\hline PCB105 & ND-0.31 & $0.029 \pm 0.062$ & 62 \\
\hline PCB138 & ND-0.13 & $0.026 \pm 0.036$ & 73 \\
\hline PCB126 & ND-0.23 & $0.030 \pm 0.058$ & 42 \\
\hline PCB187 & ND-0.061 & $0.0060 \pm 0.012$ & 38 \\
\hline PCB128+167 & ND-0.20 & $0.055 \pm 0.057$ & 69 \\
\hline PCB156 & ND-0.25 & $0.033 \pm 0.052$ & 62 \\
\hline PCB157 & ND-1.3 & $0.078 \pm 0.25$ & 35 \\
\hline PCB180 & ND-0.029 & $0.0052 \pm 0.0083$ & 27 \\
\hline PCB169 & ND-0.86 & $0.17 \pm 0.27$ & 35 \\
\hline PCB170 & ND-0.028 & $0.0047 \pm 0.0078$ & 23 \\
\hline PCB189 & ND-0.022 & $0.0015 \pm 0.0044$ & 8 \\
\hline PCB206 & ND-0.18 & $0.017 \pm 0.036$ & 54 \\
\hline$\sum \mathrm{PCBs}$ & $0.13-4.7$ & $1.7 \pm 1.2$ & \\
\hline$\sum_{\mathrm{ICES}} \mathrm{PCBS}$ & $0.088-3.4$ & $0.98 \pm 0.79$ & \\
\hline$\sum \mathrm{DL}-\mathrm{PCBs}$ & ND-1.4 & $0.56 \pm 0.46$ & \\
\hline
\end{tabular}

ND: not detected; $b$. DF: detectable frequency 
(Range: 23-1387 ng $\mathrm{g}^{-1}$ ) [21] and a Southeastern European river in Northwest Romania (Range: 2.7-253 ng $\mathrm{g}^{-1}$ ) [22]. Owing to the similarity in the toxicity and chemical properties between polychlorinated dibenzo-p-dioxins/furans and some PCBs, twelve PCB congeners including PCB 81, 77, $123,118,114,105,126,167,156,157,189$ and 169, were listed as the dioxin-like PCBs (DL-PCBs) [23]. Concentrations of $\sum$ DL-PCBs (Total concentrations of all the detectable DL-PCBs except PCB 167) ranged from "not detected" to $1.4 \mathrm{ng} \mathrm{g}^{-1}$, with an average value of $0.56 \pm 0.46 \mathrm{ng} \mathrm{g}^{-1}$. Concentrations of $\sum_{\text {ICES }}$ PCBs (Sum of PCB 28, 52, 101, 118, 138, 153 and 180) [5] varied from 0.088 to $3.4 \mathrm{ng} \mathrm{g}^{-1}$ (Mean: $0.98 \pm 0.79 \mathrm{ng} \mathrm{g}^{-1}$ ).

Fig. 1 and Fig. 2 illustrated the spatial distribution of PCBs in the SIP. The highest concentration of $\sum$ PCBs could be found in Site 5, followed by Site 6, 7, 8, 14 and 4 . The lowest concentration of $\sum$ PCBs was observed in Site 9, followed by Site 25, 24, 26, 18, 23 and 22. Among these sites, Site 5 and 4 were mainly distributed in the northern industrial area of the SIP, which might be related to the surrounding industry. However, the interesting thing was Site 9 and 18, which had low concentrations of $\sum$ PCBs, but were also located near industrial areas. In addition, Site $6,7,8$ and 14 were mainly distributed in the residential area, which might indicate that PCB contamination was closely related to the human activity intensity, but low concentrations of $\sum$ PCBs were observed in Site 22, 23, 24, 25 and 26 , which were also located near residential areas. Therefore, no correlation was found between land uses and PCB concentrations in the present research work, although PCB concentrations have been reported to be closely associated with land uses by many researchers [24].

\section{Composition and Sources Analysis of PCBs}

Tetra-PCBs (51\%) predominated in the present study area, followed by hexa-PCBs (23\%), tri-PCBs (14\%) and penta-PCBs (9.4\%), which were different from those observed in Chinese commercial PCBs: Ren et al. (2007) found tri-PCBs were the most produced and used $\mathrm{PCB}$ homologues in China and the next were tetra-PCBs [25]. This composition has been verified in transformer oil samples in China (Tri-PCBs accounted for $63 \%$ and tetra-PCBs accounted for 24\%) [26]. As can be found in Fig. 3, tri-PCBs only predominated in several sediment samples in the SIP. The dominated tetra-PCBs might be originated from the recent inputs of domestic or industrial wastewater [3, 4]. In addition, anaerobic PCB dechlorination might occur in sediments, and tetra-PCBs were usually the major dechlorinated products of highly chlorinated congeners [27]. The abundance of tetra-PCBs in the SIP might be partly due to the PCB microbial transformation, and this has also been demonstrated by the phenomenon that the light $\mathrm{PCB}$ concentration $(<5 \mathrm{Cl})$ was higher than that of the heavy PCBs $(\geq 5 \mathrm{Cl})$ in most sampling sites in the SIP, which has also been reported as an indicator of PCB anaerobic microbial reductive dechlorination [28]. Furthermore, since low chlorinated PCB congeners tended to accumulate in the atmosphere, high fractions of low chlorinated PCB here might be related to atmospheric transportation and deposition [27, 29]. However, tetra-PCBs have been reported to be mainly applied in capacitor equipment in China before, so the leakage of capacitor equipment could not be neglected in the SIP, either $[18,25]$. For the hexa-PCBs, highly chlorinated PCBs are less volatile and more lipophilic, leading them to be bound to sediment particles more

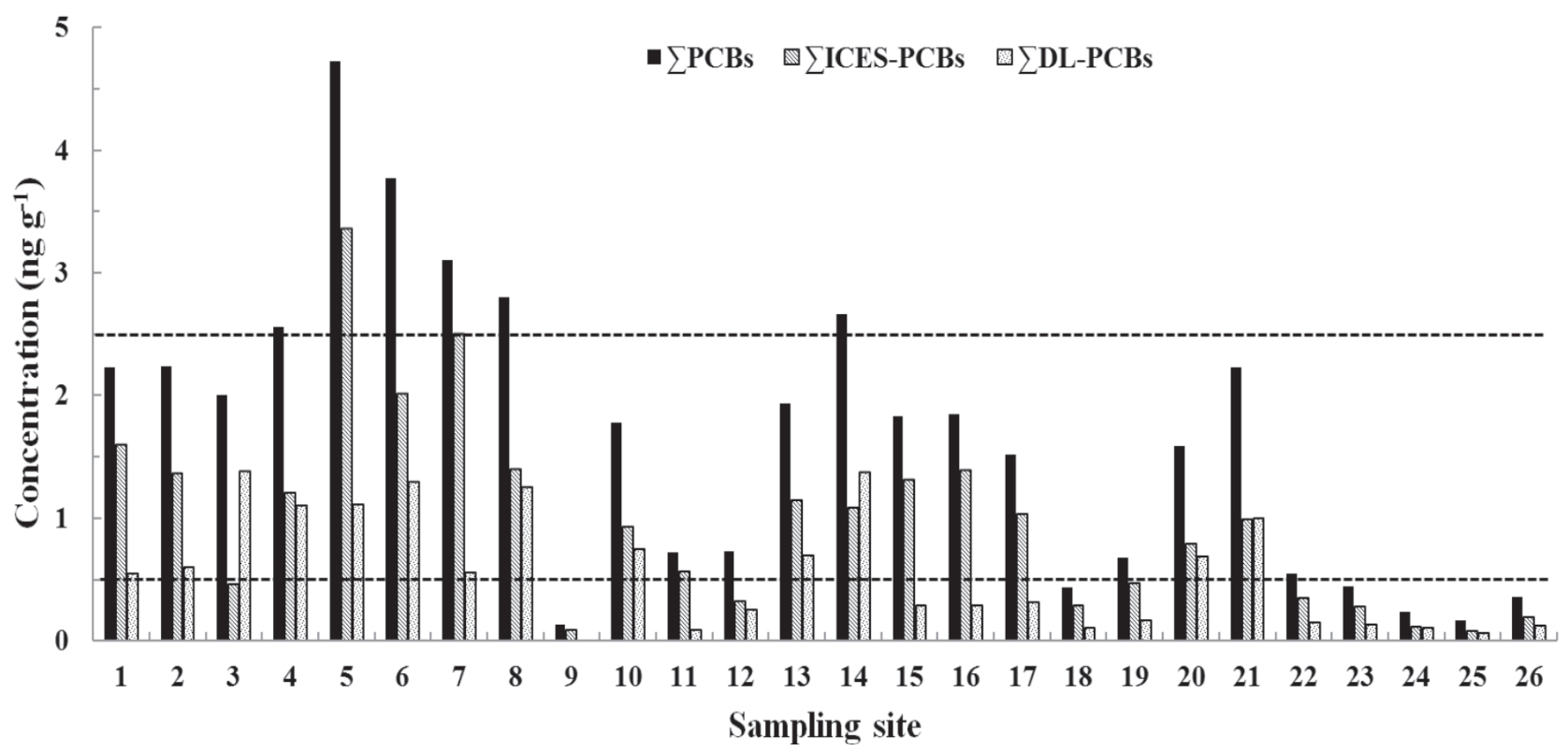

Fig. 2. Spatial distribution of PCBs in urban stream sediments of Suzhou Industrial Park, China. 


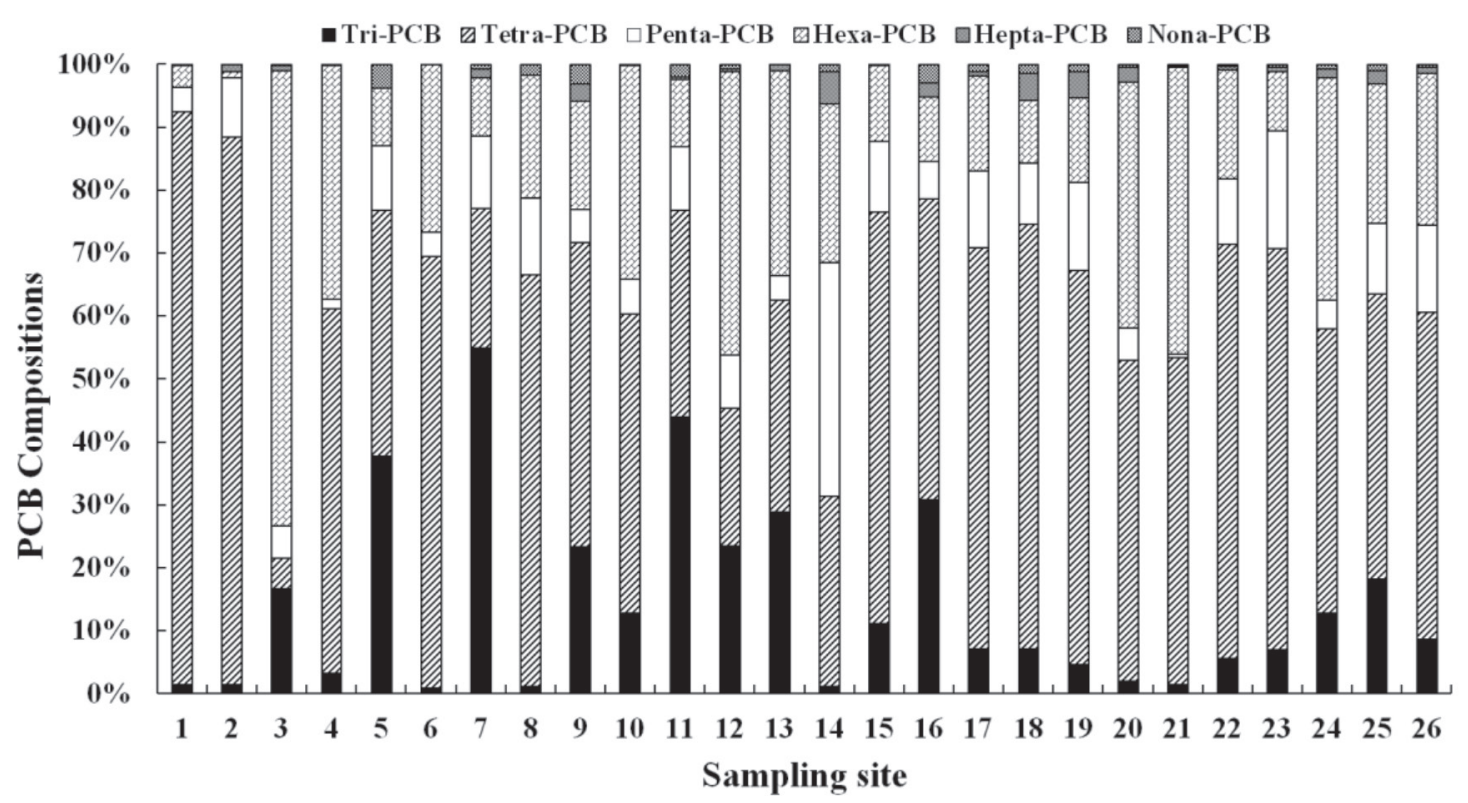

Fig. 3. PCB compositions in urban stream sediments of Suzhou Industrial Park, China.

easily and strongly [30]. Besides, Brož et al. (2000) found most hexa-PCBs were from gasoline engines in operation, and Huo et al. (2017) found they were mainly originated from imported electrical capacitors [31, 32]. Therefore, a portion of PCBs in the SIP was likely to derive from leakage of imported electrical capacitors and unintentionally formed local sources.

\section{Potential Toxicity and Risk of PCBs}

To assess the potential toxicity, the TEQ (total equivalent concentration) of DL-PCBs was calculated using the following equation: TEQ $=\sum_{i} C_{i} \times T_{E F}\left(C_{i}\right.$ is the individual DL-PCB concentration and $\mathrm{TEF}_{i}$ is the corresponding toxic equivalency factor) [33]. $\mathrm{TEF}_{\mathrm{i}}$ values of DL-PCBs were taken from the research of Van Den Berg et al. [33]. The TEQ of the EDL-PCBs in the SIP varied from "not detected" to $0.029 \mathrm{ng} \mathrm{g}^{-1}$ (Mean:
$0.0082 \mathrm{ng} \mathrm{g}^{-1}$ ) and was below the soil contamination intervention value $\left(1 \times 10^{-4} \mu \mathrm{g} \mathrm{g}^{-1}\right)$ of dioxins in China (Fig. 4) $[34,35]$. Among the detectable DL-PCBs, the TEQ of PCB 169 and PCB 126 contributed most to the PCBs toxicity in the sediments from the SIP, which accounted for $63 \%$ and $36 \%$ of the total DL-PCBs, respectively (Fig. 4). In addition, the SQG (sediment quality guidelines) was also applied for PCB ecological risk assessment here [36-38]. None of the PCB concentrations in any site of the urban stream surface sediments in the SIP had exceeded the consensus-based TEC (threshold effect concentration, $29 \mathrm{ng} \mathrm{g}^{-1}$, adverse effects will not occur when the PCB concentration below this value) or the ERL ("effects range low", $22.7 \mathrm{ng} \mathrm{g}^{-1}$, adverse effects will rarely occur if the PCB concentration below this value), indicating the adverse effects of PCBs to the aquatic life might be negligible in the SIP, China.

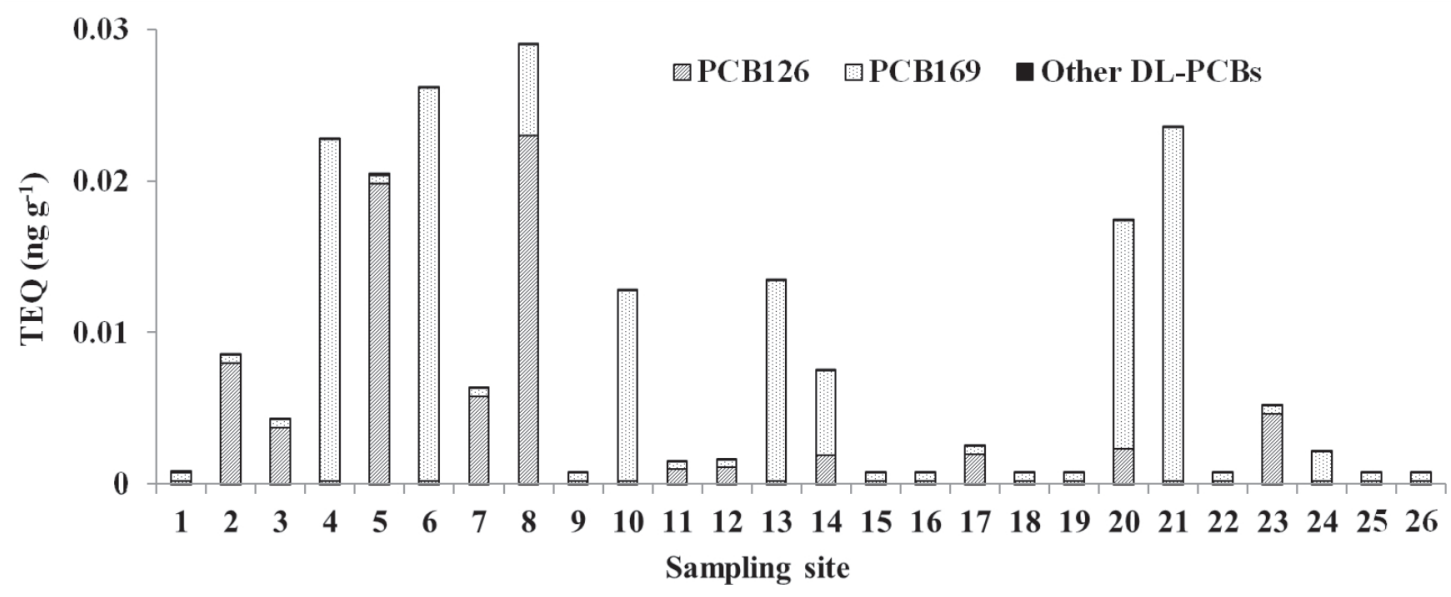

Fig. 4. TEQ (ng g ${ }^{-1}$ ) of DL-PCBs in urban stream sediments of Suzhou Industrial Park, China. 


\section{Conclusion}

In conclusion, PCBs were widely scattered in the SIP, but the contamination level was low considering the global comparison and ecological risk analysis. No correlation was found between land uses and PCBs in the SIP. Tetra-PCBs and hexa-PCBs predominated here, which were different from the composition of Chinese commercial PCBs, and might be mainly originated from other sources, such as the recent inputs of domestic or industrial wastewater, the microbial reductive dechlorination of PCBs under anaerobic conditions, atmospheric transportation and deposition, leakage of imported electrical capacitors, and some unintentionally formed local sources.

\section{Acknowledgments}

This work was supported by the National Natural Science Foundation of China (42002183 and 41203075), the Natural Science Foundation of Anhui Province (1808085QD98), the doctoral start-up funds of Anhui Normal University (2018XJJ51), China Scholarship Council (to Xiaoguo $\mathrm{Wu}$ ), the Innovation and entrepreneurship training program of Anhui Normal University (202010370228), and the University Natural Science Research Project of Anhui Province (KJ2020A0062).

\section{Conflict of Interest}

The authors declare no conflict of interest.

\section{References}

1. ILIC P., NISIC T., FAROOQI Z.U.R. Occurrence of Specific Polychlorinated Biphenyls Congeners in an Industrial Zone. Polish Journal of Environmental Studies, 30 (1), 635, 2021.

2. ALEGRIA H., MARTINEZ-COLON M., BIRGUL A., BROOKS G., HANSON L., KURT-KARAKUS P. Historical sediment record and levels of PCBs in sediments and mangroves of Jobos Bay, Puerto Rico. Science of The Total Environment, 573, 1003, 2016.

3. WANG W., BAI J., ZHANG G., JIA J., WANG X., LIU X., CUI B. Occurrence, sources and ecotoxicological risks of polychlorinated biphenyls (PCBs) in sediment cores from urban, rural and reclamation-affected rivers of the Pearl River Delta, China. Chemosphere, 218, 359, 2019.

4. YANG Z., SHEN Z., GAO F., TANG Z., NIU J. Occurrence and possible sources of polychlorinated biphenyls in surface sediments from the Wuhan reach of the Yangtze River, China. Chemosphere, 74 (11), 1522, 2009.

5. WU X., CHEN A., WANG S., ZOU J., LIU H., XIAO S. Polychlorinated biphenyls in two typical landforms of Southern Anhui province, China: Sources, air-soil exchange, and risk assessment. Atmospheric Pollution Research, 9 (3), 569, 2018.
6. DUAN X., LI Y., LI X., LI M., ZHANG D. Distributions and sources of polychlorinated biphenyls in the coastal East China Sea sediments. Science of The Total Environment, 463, 894, 2013.

7. WU Z., LIN T., LI A., ZHOU S., HE H., GUO J., HU L., LI Y., GUO Z. Sedimentary records of polychlorinated biphenyls in the East China Marginal Seas and Great Lakes: Significance of recent rise of emissions in China and environmental implications. Environmental Pollution, 254, 112972, 2019.

8. ABBASSY M.M.S. Distribution pattern of persistent organic pollutants in aquatic ecosystem at the Rosetta Nile branch estuary into the Mediterranean Sea, North of Delta, Egypt. Marine Pollution Bulletin, 131, 115, 2018.

9. SIP. Investment Guide of Suzhou Industrial Park. Available online: http://www.sipac.gov.cn/english/InvestmentGuide/ SinoSingaporeCooperation/20 1904/t20190409_1013816. htm (accessed on $9^{\text {th }}$ April 2019).

10. YUAN Z., HE B., WU X., SIMONICH S.L.M., LIU H., FU J., CHEN A., LIU H., WANG Q. Polycyclic aromatic hydrocarbons (PAHs) in urban stream sediments of Suzhou Industrial Park, an emerging eco-industrial park in China: Occurrence, sources and potential risk. Ecotoxicology and Environmental Safety, 214, 112095, 2021.

11. YU C., DIJKEMA G.P.J., DE JONG M., SHI H. From an eco-industrial park towards an eco-city: a case study in Suzhou, China. Journal of Cleaner Production, 102, 264, 2015.

12. LI Y., LONG L., GE J., YANG L., CHENG J., SUN L., LU C., YU X. Presence, distribution and risk assessment of polycyclic aromatic hydrocarbons in rice-wheat continuous cropping soils close to five industrial parks of Suzhou, China. Chemosphere, 184, 753, 2017.

13. WEI Y.H.D., LU Y., CHEN W. Globalizing Regional Development in Sunan, China: Does Suzhou Industrial Park Fit a Neo-Marshallian District Model? Regional Studies, 43 (3), 409, 2009.

14. LADISLAS S., GERENTE C., CHAZARENC F., BRISSON J., ANDRES Y. Floating treatment wetlands for heavy metal removal in highway stormwater ponds. Ecological Engineering, 80, 85, 2015.

15. SIP. Scientific Masterplan (2012-2030) of Suzhou Industrial Park. Available online: http://www.sipac.gov.cn/ szgyyqenglish/scientific/list_tt.shtml (accessed on $4^{\text {th }}$ July 2011).

16. ZHONG T., NIU N., LI X., ZHANG D., ZOU L., YAO S. Distribution, composition profiles, source identification and potential risk assessment of Polychlorinated Biphenyls (PCBs) and Dechlorane Plus (DP) in sediments from Liaohe Estuary. Regional Studies in Marine Science, 36, 101291, 2020.

17. MEHDINIA A., BATENI F., JAHEDI VAIGHAN D., SHEIJOONI FUMANI N. Occurrence of polychlorinated biphenyl congeners in marine sediment of Makran region, Chabahr bay, Iran. Marine Pollution Bulletin, 164, 112038, 2021.

18. YANG J., QADEER A., LIU M., ZHU J.M., HUANG Y.P., DU W.N., WEI X.Y. Occurrence, source, and partition of PAHs, PCBs, and OCPs in the multiphase system of an urban lake, Shanghai. Applied Geochemistry, 106, 17, 2019.

19. CHEN L., YANG Y., CHEN J., GAO S., QI S., SUN C., SHEN Z. Spatial-temporal variability and transportation mechanism of polychlorinated biphenyls in the Yangtze River Estuary. Science of The Total Environment, 598, 12, 2017. 
20. FOSTER G.D., WALLS C., MCEACHERN P.R., HUFF T.B., MCBRIDE R. Sedimentary profiles of pollution marker chemicals along a large tributary of Chesapeake Bay (mid-Atlantic USA). Journal of Soils and Sediments, 19 (3), 1511, 2019.

21. NEIRA C., VALES M., MENDOZA G., HOH E. Levin L.A. Polychlorinated biphenyls (PCBs) in recreational marina sediments of San Diego Bay, southern California. Marine Pollution Bulletin, 126, 204, 2018.

22. BARHOUMI B., BELDEAN-GALEA M.S., ALRAWABDEH A.M., ROBA C., MARTONOS I.M., BĂLC R., KAHLAOUI M., TOUIL S., TEDETTI M., DRISS M.R., BACIU C. Occurrence, distribution and ecological risk of trace metals and organic pollutants in surface sediments from a Southeastern European river (Someşu Mic River, Romania). Science of The Total Environment, 660, 660, 2019.

23. FANG M., CHOI S.D., BAEK S.Y., JIN G., CHANG Y.S. Deposition of polychlorinated biphenyls and polybrominated diphenyl ethers in the vicinity of a steel manufacturing plant. Atmospheric Environment, 49, 206, 2012.

24. YU H., LIU Y., SHU X., MA L., PAN Y. Assessment of the spatial distribution of organochlorine pesticides (OCPs) and polychlorinated biphenyls (PCBs) in urban soil of China. Chemosphere, 243, 125392, 2020.

25. REN N.Q., QUE M., LI Y., LIU Y., WAN X., XU D., SVERKO E., MA J. Polychlorinated Biphenyls in Chinese Surface Soils. Environmental Science \& Technology, 41 (11), 3871, 2007.

26. JIANG Q.L., ZHOU H.Y., XU D.D., CHAI Z.F., LI Y.F. Characteristics of PCB congeners and homologs in Chinese transformer oil. China Environmental Science, 27 (5), 608, 2007 [In Chinese].

27. DENG Z., LI X., CHEN C., ZHANG N., ZHOU H., WANG H., HAN X., ZHANG C. Distribution characteristics and environmental fate of PCBs in marine sediments at different latitudinal regions: Insights from congener profiles. Marine Pollution Bulletin, 161, 111710, 2020.

28. FRASER M.A., CHEN L., ASHAR M., HUANG W., ZENG J., ZHANG C., ZHANG D. Occurrence and distribution of microplastics and polychlorinated biphenyls in sediments from the Qiantang River and Hangzhou Bay, China. Ecotoxicology and Environmental Safety, 196, 110536, 2020.

29. BRIGHT D.A., DUSHENKO W.T., GRUNDY S.L., REIMER K.J. Evidence for short-range transport of polychlorinated biphenyls in the Canadian Arctic using congener signatures of PCBs in soils. Science of The Total Environment, 160-161, 251, 1995.
30. REN G., YAN X., CHU X., CAI Y., SHI Y., ZHENG K., YU Z. Polybrominated diphenyl ethers and polychlorinated biphenyls in mangrove sediments of Shantou, China: Occurrence, profiles, depth-distribution, and risk assessment. Ecotoxicology and Environmental Safety, 183, 109564, 2019.

31. BROŽ J., GRABIC R., KILIÁN J., LOJKÁSEK M., MARKLUND S., OCELKA T., PEKÁREK V., PŘIBYL J., TYDLITÁT V., VÝŠKA J. The effect of oils on PAH, PCDD, PCDF, and PCB emissions from a spark engine fueled with leaded gasoline. Chemosphere, 41 (12), 1905, 2000.

32. HUO S., LI C., XI B., YU Z., YEAGER K.M., WU F. Historical record of polychlorinated biphenyls (PCBs) and special occurrence of PCB 209 in a shallow fresh-water lake from eastern China. Chemosphere, 184, 832, 2017.

33. VAN DEN BERG M., BIRNBAUM L.S., DENISON M., DE VITO M., FARLAND W., FEELEY M., FIEDLER H., HAKANSSON H., HANBERG A., HAWS L., ROSE M., SAFE S., SCHRENK D., TOHYAMA C., TRITSCHER A., TUOMISTO J., TYSKLIND M., WALKER N., PETERSON R.E. The 2005 World Health Organization Reevaluation of Human and Mammalian Toxic Equivalency Factors for Dioxins and Dioxin-like compounds. Toxicological Sciences, 93 (2), 223, 2006.

34. MINISTRY OF ECOLOGY AND ENVIRONMENT OF THE PEOPLE'S REPUBLIC OF CHINA. Soil environment quality risk control standard for soil contamination of development land (GB36600-2018), Beijing, China, 2018 [In Chinese].

35. YUAN Z., LIU G., LAM M.H.W., LIU H., WANG S., DA C. Occurrence and Potential Risk of Polychlorinated Biphenyls in Surface Soils from the Yellow River Delta Natural Reserve, China. Bulletin of Environmental Contamination and Toxicology, 102 (6), 843, 2019.

36. LONG E.R., MACDONALD D.D., SMITH S.L., CALDER F.D. Incidence of adverse biological effects within ranges of chemical concentrations in marine and estuarine sediments. Environmental Management, 19 (1), 81, 1995.

37. GÓMEZ-GUTIÉRREZ A., GARNACHO E., BAYONA J.M., ALBAIGÉS J. Screening ecological risk assessment of persistent organic pollutants in Mediterranean sea sediments. Environment International, 33 (7), 867, 2007.

38. NIEWIADOWSKA A., KILJANEK T., SEMENIUK S. Contamination of Fish and Sediments from the Vistula River by Organochlorine Pesticides and PCBs. Polish Journal of Environmental Studies, 24 (5), 2315, 2015. 